\title{
PENGARUH KEDISIPLINAN SISWA DI SEKOLAH TERHADAP PRESTASI BELAJAR SISWA TEKNIK PENDINGIN
}

\author{
Eka S. Ariananda ${ }^{1}$, Syamsuri Hasan², Maman Rakhman ${ }^{3}$ \\ Departemen Pendidikan Teknik Mesin \\ Universitas Pendidikan Indonesia \\ Jl. Dr. Setiabudhi No. 207 Bandung 40154 \\ saputraariananda@gmail.com
}

\begin{abstract}
ABSTRAK
Penelitian ini bertujuan untuk mengetahui tingkat kedisiplinan siswa kelas XI di SMK TI Cimahi TP serta pengaruh kedisiplinan siswa pada mata pelajaran Sistem Refrigerasi. Metode yang digunakan dalam penelitian ini adalah metode deskriptif dengan teknik pengumpulan data berupa angket dan dokumentasi nilai ujian akhir semester (UAS) mata pelajaran Sistem Refrigerasi dengan jumlah responden 77 siswa. Hasil dari penelitian menunjukkan bahwa persentase kedisiplinan siswa kelas XI di SMK TI Cimahi adalah 55\% dikategorikan maka kedisiplinana siswa tergolong kurang baik. Berdasarkan hasil uji hipotesis terdapat pengaruh kedisiplinan siswa di sekolah dengan prestasi belajar siswa pada mata pelajaran sistem refrigerasi.
\end{abstract}

Kata kunci: disiplin, prestasi, refrigerasi, pendingin

\section{PENDAHULUAN}

Mata pelajaran Sistem Refrigerasi (SR) merpakan salah satu mata pelajaran yang ada pada program studi keahlian Teknik Pendingin di SMK TI Cimahi. Mata pelajaran ini ada dan dipelajari di kelas XI. Mata pelajaran ini membahas tentang dasar-dasar sistem refrigerasi, komponen-komponen sistem refrigerasi dan aplikasi sistem refrigerasi.

Berdasrkan pengamatan ketika melaksanakan PLP di SMKN TI Cimahi, kedisiplinan siswa di sekolah terlihat kurang. Banyak pelanggaran tata tertib dan peraturan yang dilakukan oleh siswa. Pelanggaran yang sering dilakukan siswa seperti datang terlambat kesekolah, tidak mengerjakan tugas, banyak siswa yang diam di kantin saat jam pelajaran berlangsung dan banyak pelanggaran lainnya. Hal ini karena tata tertib dan peraturan sekolah yang di buat tidak diberlakukan secara tegas oleh sekolah. Kondisi tersebut mempengaruhi situasi belajar yang kurang kondusif sehingga berpengaruh pada prestasi belajar yang dicapai oleh siswa. Tujuan dilakukannya penelitian ini adalah untuk mengetahui tingkat kedisiplinan siswa di sekolah dan untuk mengetahui pengaruh kedisiplinan siswa di sekolah terhadap prestasi belajar siswa pada mata pelajaran Sistem Refrigerasi (SR).

Kualitas pendidikan dapat diketahui dari kedisiplinan setiap individu atau siswa baik dalam lingkungan sekolahnya maupun lingkungan bermasyarakat. Belajar merupakan salah

\footnotetext{
${ }^{1}$ Mahasiswa Departemen Pendidikan Teknik Mesin FPTK UPI

2 Dosen Departemen Pendidikan Teknik Mesin FPTK UPI

${ }^{3}$ Dosen Departemen Pendidikan Teknik Mesin FPTK UPI
} 
satu faktor yang dapat meningkatkan kualitas sumber daya manusia. Saat ini, pemerintah melalui pendidikan Sekolah Menengah Kejuruan (SMK) berusaha untuk mencetak lulusan yang terampil dan siap memasuki lapangan kerja. Melalui SMK, lulusannya dituntut untuk memiliki keterampilan yang kompeten dibidannya agar kelak mampu bersaing di dunia industri. Untuk mencapai tuntutan tersebut maka diperlukan pula proses pembelajaran yang baik. Upaya sekolah untuk menciptakan proses pembelajaran yang baik memberlakukan tata tertib sekolah agar siswa menjadi disiplin. Tata tertib sekolah merupakan kumpulan peraturan yang harus di taati atau dilaksanakan di sekolah oleh seluruh siswa agar proses pembelajaran berlangsung lancar. Peraturan sekolah sebagai suatu keharusan untuk dipatuhi oleh para siswa yang bertujuan agar siswa terbiasa dengan mematuhi peraturan dan menjadikan siswa disiplin terhadap diri sendiri.

Siswa atau biasa disebut dengan peserta didik adalah anggota masyarakat yang berusaha mengembangkan potensi diri melalui proses pembelajaran yang tersedia pada jalur, jenjang dan jenis pendidikan tertentu ( UU RI No. 20/2003 pasal 1 ayat 4 Sisdiknas). Siswa terlibat langsung dalam dunia pendidikan, melalui sekolah siswa mendapatkan pendidikan dengan berlangsungnya proses pembelajaran. Proses penbelajaran dapat berlangsung di dalam kelas ataupun di luar kelas dengan bimbingan seorang guru. Melalui pendidikan siswa belajar untuk mengenal diri, belajar mengenal orang lain, dan belajar mengenal lingkungan sekitarnya.

Pengendalian diri harus dikembangkan pada diri siswa, pengendalian diri yang dimaksud adalah suatu kondisi dimana seseorang dalam perbuatannya selalu dapat menguasai diri sehingga tetap mengontrol dirinya dari berbagai keinginan yang terlalu berlebihan. Pengendalian diri tersebut terkandung keteraturan hidup dan kepatuhan akan segala peraturan, dengan kata lain perbuatan siswa selalu berada dalam koridor disiplin dan tata tertib sekolah. Maka hal tersebut akan menumbuhkan rasa kedisiplinan siswa untuk mngikuti tiap peraturan yang berlaku di sekolah.

Ada terdapat banyak definisi yang dikemukakan oleh para ahli mengenai kedisiplinan. Salah satunya yang mengemukakan bahwa kedisiplinan berasal dari kata disiplin, yang berarti sikap mental yang mengandung kerelaan untuk mematuhi semua ketentuan peraturan dan norma yang berlaku dalam menunaikan tugas dan tanggung jawab (Gunarsa, 2008). Disiplin secara lengkap adalah kesadaran untuk melakukan sesuatu hal dengan tertib dan teratur sesuai dengan peraturan-peraturan yang berlaku dengan penuh tanggung jawab tanpa paksaan dari siapa pun. 
Seiring perkembangan zaman, kata "discipline" yang berasal dari bahasa Inggris berarti kepatuhan atau yang menyangkut tata tertib. Istilah disiplin dalam Bahasa Indonesia kerapkali terkait dan menyatu dengan tata tertib dan ketertiban. Istilah ketertiban mempunyai arti kepatuhan seseorang dalam mengikuti peraturan atau tata tertib karena didorong atau disebabkan oleh sesuatu yang datang dari luar dirinya (Prijodarminto, 2004). Sebaliknya istilah disiplin sebagai kepatuhan dan ketaatan yang muncul karena adanya kesadaran dan dorongan dari dalam diri sendiri. Tata tertib berarti seperangkat peraturan yang berlaku untuk menciptakan kondisi yang tertib dan teratur.

Sikap kedisiplinan penting dan harus dimiliki oleh setiap siswa. Disiplin membantu siswa dalam proses pembentukan sikap, prilaku dan akan mengantar seorang siswa sukses dalam belajar dan ketika bekerja nanti. Fungsi kedisiplinan antara lain, (Tu'u, 2004) yaitu: menata kehidupan bersama, disiplin berguna untuk menyadarkan seseorang bahwa dirinya perlu menghargai dengan cara mentaati dan mematuhi peraturan yang berlaku. Sehingga tidak merugikan pihak lain dan hubungan dengan sesama menjadi baik. Membangun kepribadian pertumbuhan, kepribadian seseorang biasanya dipengaruhi oleh faktor lingkungan. Disiplin yang diterapkan di masing-masing lingkungan tersebur memberi dampak bagi pertumbuhan kepribadian yang baik. Oleh karena itu, dengan sikap disiplin seseorang akan terbiasa mengikuti, mematuhi aturan yang berlaku dan kebiasaan itu lama-kelamaan akan membiasakan dirinya dalam membangun kepribadian yang baik. Melatih kepribadian, sikap, prilaku dan pola kehidupan yang baik dan berdisiplin tidak terbentuk serta-merta dalam waktu singkat. Namun, terbentuk melalui satu proses yang membutuhkan waktu panjang. Salah satu proses untuk membentuk kepribadian tersebut dilakukan melalui latihan. Disiplin dapat terjadi karena dorongan kesadaran diri, dengan kesadaran yang datang dari diri sendiri ini sikap kedisiplinan akan lebih baik. Sebaliknya, disiplin dapat pula terjadi karena adanya pemaksaan dan tekanan dari luar.

Keberhasilan siswa dalam studinya dipengaruhi oleh cara belajarnya. Siswa yang memiliki cara belajar yang efektif memungkinkan untuk mencapai hasil atau prestai yang lebih tinggi daripada siswa yang tidak mempunyai cara belajar yang efektif. Untuk belajar secara efektif dan efisien diperlukan kesadaran dan disiplin tinggi setiap siswa. Siswa yang memiliki disiplin dalam belajarnya akan berusaha mengatur dan menggunakan strategi dan cara belajar yang tepat baginya. Jadi langkah pertama yang perlu dimiliki agar dapat belajar secara efektif dan efisien adalah kesadaran atas tanggung jawab pribadi dan keyakinan bahwa 
belajar adalah untuk kepentingan diri sendiri, dilakukan sendiri dan tidak menggantungkan nasib pada orang lain (Hamalik, 2005).

\section{METODE PENELITIAN}

Metode yang digunakan dalam penelitian ini adalah metode deskriptif yang ditujukan untuk menggambarkan fenomena-fenomena yang ada, yang berlangsung pada saat ini atau saat yang lampau. Variabel penelitian dibagi menjadi dua, yaitu variabel bebas kedisiplinan siswa di sekolah (X) dan variabel terikat prestasi belajar (Y). Populasi yang digunakan dalam penelitian ini adalah siswa kelas XI Program Keahlian Teknik Pendingin SMK TI Cimahi yang terdiri dari dua kelas dengan jumlah 77 orang. Sampel yang digunakan dalam penelitian ini pun berjumlah 77 orang. Teknik pengumpulan data berupa angket untuk siswa, dokumentasi nilai UAS siswa.

Pada penelitian ini digunakan teknik analisis data secara kuantitatif melalui metode statistik yang meliputi uji normalitas, uji homogenitas, uji korelasi, uji koefisien determinasi, uji regresi linier sederhana dan uji hipotesis. Ada pun hipotesis yang diajukan pada penelitian ini adalah terdapat pengaruh kedisiplinan siswa di sekolah terhadap prestasi belajar siswa pada mata pelajaran sistem refrigerasi.

\section{HASIL PENELITIAN}

Analisis uji korelasi dilakukan untuk mengetahui seberapa besar hubungan antara variabel $\mathrm{X}$ dan Y. Statistik yang digunakan untuk mengetahui hubungan ini adalah dengan statistik non-parametrik menggunakan korelasi Spearman Rank. Hasil yang diperoleh menggunakan korelasi Spearman Rank adalah nilai korelasi sebesar 0,429. Jika dikonsultasikan dengan tabel intrepratsi r, maka nilai korelasi 0,429 memiliki kriteria sedang. Kontribusi dari kedisiplinan di sekolah terhadap prestasi belajar siswa pada mata pelajaran system refrigerasi diperoleh dengan rumus KD yang besarnya 18\%. Artinya kedisiplinan siswa di sekolah memberikan kontribusi efektif terhadap prestasi belajar siswa pada mata pelajaran system refrigerasi sebesar $18 \%$ dan sisanya $82 \%$ dipengaruhi oleh faktor lain.

Persamaan regresi untuk variabel $\mathrm{X}$, yaitu pengaruh kedisiplinan siswa di sekolah adalah $Y=28,287+0,43 X$. Hasil uji signifikan regresi untuk $F_{\text {hitung }}$ sebesar 17,61 dengan taraf kesalahan $\alpha=0,05$, derajat kebebasan (dk) pembilang $=1$ dan derajat kebebasan (dk) penyebut $=75$ didapat $F_{\text {tabel }}=3,968$. Hal ini menunjukkan $F_{\text {hitung }}>F_{\text {tabel }}$ yaitu 17,61 > 3,968, maka dengan demikian koefesien arah regresi signifikan pada taraf kesalahan 0,05 dan model 
regresi terbukti linier karena $F_{\text {hitung }}>F_{\text {tabel }}$ yaitu 143,83 $>1,712$, dengan (dk) pembilang $=31$ dan $(\mathrm{dk})$ penyebut $=44$. Makna dari persamaan $\mathrm{Y}=28,287+0,43 \mathrm{X}$ adalah karena $\mathrm{b}(0,43)$ positif, maka hubungan fungsionalnya juga positif. Artinya semakin tinggi variabel kedisiplinan siswa di sekolah, maka akan semakin tinggi pula variabel prestasi belajar.

Agar hasilnya lebih dapat dipertanggungjawabkan dalam mengambil keputusan, maka dilakukan uji signifikansi dan linieritasnya. Hasil uji signifikansi regresi diperoleh bahwa koefisien arah regresi signifikan dan model regresi terbukti linier pada taraf kesalahan 0,05.

Pengaruh yang tidak terlalu kuat juga bisa dilihat koefisien determinasi sebesar $18 \%$. Maknanya adalah kedisiplinan siswa memberi kontribusi efektif terhadap prestasi belajar siswa pada mata pelajaran Sistem Refrigerasi sebesar $18 \%$ dan $82 \%$ sisanya dipengaruhi oleh faktor lain yang tidak dianalisis.

Pengujian hipotesis yang dilakukan dalam penelitian ini bertujuan untuk menerima atau menolak hipotesis dan ada atau tidaknya pengaruh dari variabel penelitian yang diajukan. Adapun hipotesis yang diajukan adalah terbukti, berdasarkan hasil perhitungan uji t-student diperoleh hasil yang menyimpulkan bahwa hipotesis yang diajukan dalam penelitian ini diterima pada taraf kesalahan 0,05 .

\section{PEMBAHASAN}

Berdasarkan interpretasi yang di dapat kedisiplinan siswa terlihat bahwa kedisiplinan siswa masih tergolong kurang baik, karena diketahui bahwa kedisiplinan siswa yang dilihat dari beberapa aspek seperti, kehadiran di kelas/lab.praktek berada dalam kategori kurang baik (56\%) dan etika dan sopan santun berada dalam kategori kurang baik (52\%). Indikator ketepatan penyelesaian tugas berada dalam kategori kurang baik (57\%) dan indikator kerapihan berpakaian pada saat praktek berada dalam kategori kurang baik (54\%) dan indikator menyimak pelajaran berada dalam kategori kurang baik juga (56\%). Adapun sikap disiplin yang harus dimiliki siswa seperti mematuhi tata tertib dan peraturan sekolah yang ada karena kedisiplinan sangat erat kaitannya dengan hal tersebut. Sikap disiplin yang diharapkan siswa dapat berperiaku sesuai dengan ketentuan atau peraturan yang berlaku sehingga diperoleh hasil yang maksimal dalam segala aspek dan menciptakan kegiatan pembelajaran yang baik.

Prestasi belajar yang dicapai siswa pun hanya sebagian siswa yang memenuhi KKM, masih banyak siswa yang prestasinya belum memenuhi KKM. Hal tersebut bisa terjadi karena kurang tegasnya sekolah menjalankan peraturan dan tata tertib yang sudah ada di sekolah. 
Pengaruh kedisiplinan siswa di sekolah terhadap prestasi belajar siswa pada mata pelajaran SR menunjukkan arah yang positif (Arikunto, 2006). Hal ini bermakna bahwa semakin rendah kedisiplinan siswa di sekolah, maka prestasi belajar juga akan semakin rendah atau sebaliknya semakin tinggi kedisiplinan siswa di sekolah, maka prestasi belajar juga akan semakin tinggi. Hal tersebut menunjukan, disiplin yang muncul karena kesadaran diri, siswa berhasil dalam belajarnya. Sebaliknya, siswa yang kerap kali melanggar ketentuan sekolah pada umumnya terhambat prestasinya.

Kedisiplinan siswa tidak bisa dibangun dengan sendirinya, karena kedisiplinan siswa bisa terwujud atas dasar kesadaran dalam diri masing-masing siswa. Perlu adanya peran penting sekolah dalam mewujudkan kedisiplinan siswa agar tercapainya prestasi siswa yang baik pula (Yudhawati dan Haryanto, 2011). Oleh sebab itu, peran sekolah untuk mendisiplinkan siswa yaitu dengan membuat aturan-aturan dan tata tertib yang diberlakukan secara tegas dan konsisten. Jika aturan dan tata tertib tersebut diberlakukan secara tegas dan konsisten, maka siswa yang pada awalnya terpaksa dengan aturan dan tata tertib yang ada akan merasa terbiasa mematuhinya. Peraturan dan tata tertib yang diberlakukan secara tegas dan konsisten diharapkan akan meningkatkan kedisiplinan siswa yang berdampak pada tercapainya prestasi belajar yang baik pula.

\section{KESIMPULAN}

Kesimpulan dari penelitian ini yaitu kedisiplinan siswa tergolong kurang baik sehingga prestasi belajar siswa pada mata pelajaran SR berada dibawah KKM. Kedisiplinan siswa di sekolah berpengaruh terhadap prestasi belajar siswa pada mara pelajaran sistem refrigerasi.

\section{DAFTAR PUSTAKA}

Arikunto, S. (2006). Dasar-Dasar Evaluasi Pendidikan. Jakarta: Bumi Aksara.

Gunarsa, S. D. (2008). Psikologi Perkembangan Anak dan Remaja. Jakarta: PT. BPK Gunung Mulia.

Hamalik, O. (2005). Metode Belajar dan Kesulitan-kesulitan Belajar. Bandung: Tarsito.

Prijodarminto. (2004). Disiplin: Kiat Menuju Sukses. Jakarta: Pradnya Paramita.

Tu'u, T. (2004). Peran Disiplin pada Prilaku dan Prestasi Siswa. Jakarta: Grasindo.

Yudhawati, R. \& Haryanto, D. (2011). Teori-teori Dasar Psikologi Pendidikan. Jakarta: Prestasi Pusaka. 